\title{
Вера Вениаминовна Хвостова и зарождение генетики мейоза
}

\section{И.Н. Голубовская凶}

Аннотация: Статья рассказывает, как профессор Вера Вениаминовна Хвостова организовала в ИЦиГСО АН СССР в начале 1960-х годов лабораторию цитогенетики растений, как обучала молодых сотрудников постижению этой захватывающей области генетики, поддерживала все новое и помогала выбрать путь в науке и жизни. Освещены этапы зарождения и становления генетики мейоза - нового направления в цитогенетике растений, которое появилось лишь при благословении и полной поддержке Веры Вениаминовны. Работа проиллюстрирована примерами исследований автора по цитогенетике мутаций мейоза у кукурузы на

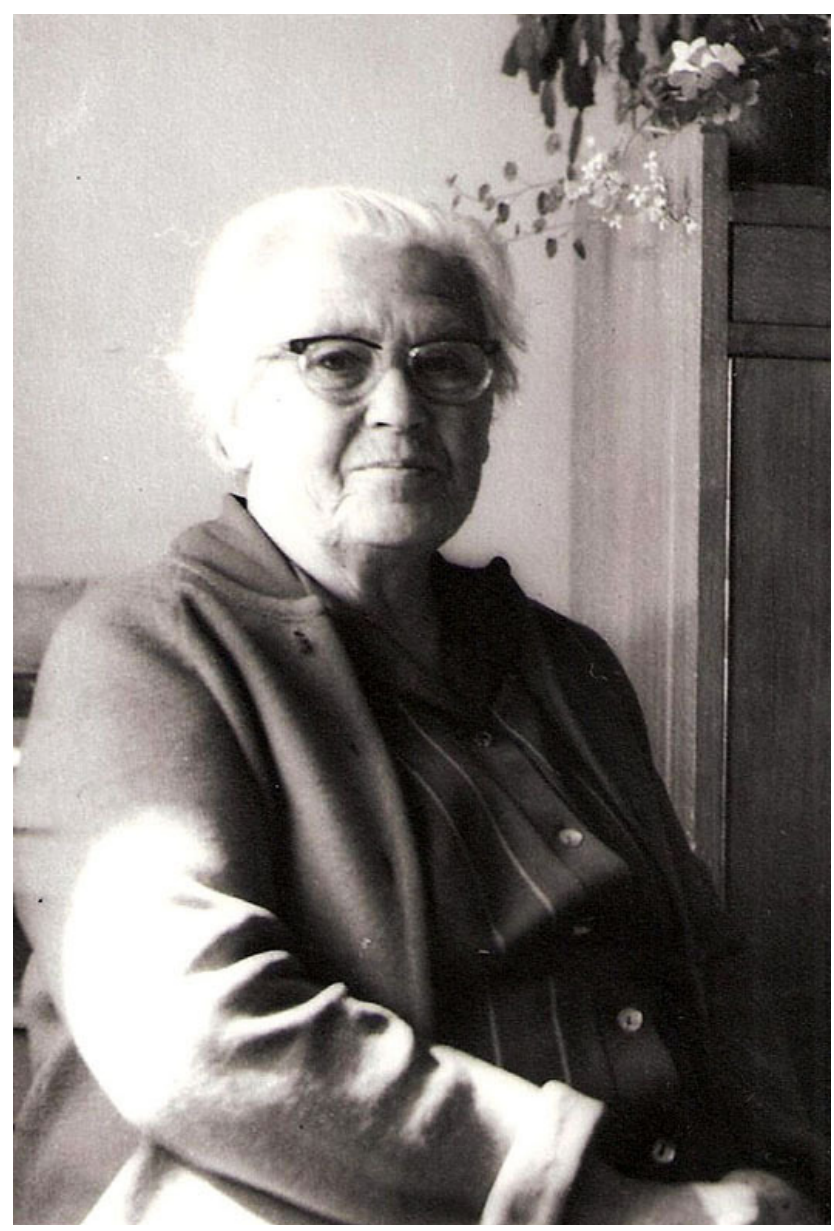

Вера Вениаминовна Хвостова. Новосибирск, Академгородок, 1974 уровне электронной микроскопии и молекулярной цитологии с использованием FISH (флуоресцентная гибридизация in situ) и иммуноокраски с антителами против белков синаптонемального комплекса.

Ключевые слова: В.В. Хвостова; мейоз у растений; гомологичная конъюгация; синаптонемальный комплекс; центромер; сестринские хроматиды; гомеологичные геномы.

Благодарности: Автор благодарит мужа, Михаила Давидовича Голубовского, за поддержку и помощь в редактировании текста; Николая Петровича Гончарова за внимательное прочтение текста и ценные советы по оформлению рукописи; редакцию «Писем в Вавиловский журнал генетики и селекции» за прекрасную коммуникацию.

Для цитирования: Голубовская И.Н. Вера Вениаминовна Хвостова и зарождение генетики мейоза. Письма в Вавиловский журнал генетики и селекции. 2021;7(2):96-108. DOI 10.18699/LettersVJ2021-7-11

\section{Cell biology}

\section{Vera V. Khvostova and origin of genetics of meiosis}

\section{I.N. Golubovskaya $\bowtie$}

Abstract: The purpose of the article is to tell by my own experience how Professor Vera V. Khvostova organized at the Institute of Cytology and Genetics (Novosibirsk, Russia) in the early 1960-s laboratory of plant cytogenetics. How she has taught us young fellows how to comprehend this fascinated area of genetics. She supported everything new and helped to choose ours own path in science and life. I highlighted the first steps in the birth and coming into being of genetics of meiosis - a new direction in plant cytogenetics. It appeares to be possible only 
with the blessing and full support of Vera Khvostova. The article is illustrated with some examples of my studies of the cytogenetics of meiotic maize mutants at the level of transmission electron microscopy and molecular cytology with FISH and immunostaining with antibodies against synaptonemal complex proteins.

Key words: Vera Khvostova; meiosis in plants; homologous synapsis; synaptonemal complex; centromere; sister chromatids; homeologous genomes.

For citation: Golubovskaya I.N. Vera V. Khvostova and origin of genetics of meiosis. Pisma v Vavilovskii Zhurnal Genetiki i Selektsii = Letters to Vavilov Journal of Genetics and Breeding. 2021;7(2):96-108. DOI 10.18699/LettersVJ2021-7-11 (in Russian)

\section{Вера Вениаминовна - какой я ее знала}

Вера Вениаминовна Хвостова - уникальный человек и ученый. Писать о ней трудно, ибо она имела столько друзей и учеников, что все хорошие слова уже разобраны и все о ней сказано (100-летие со дня рождения..., 2003; Шумный и др., 2010, 2012). Новые слова трудно придумать, а старые повторять не хочется. В представленных заметках я расскажу о запомнившихся эпизодах исследований, выполненных с коллегами в лаборатории цитогенетики Института цитологии и генетики (ИЦиГ) СО АН СССР, которую возглавляла Вера Вениаминовна. Подобно Пигмалиону, она лепила из нас, учеников, восторженных экспериментаторов, учила критически мыслить и отстаивать свою точку зрения. На памятных примерах из собственного опыта я поделюсь тем, как нелегко в ходе исследований рождается истина и сколь велика была роль нашего учителя в ее познании.

В.В. была не только моим учителем-наставником, но и доверенным другом. Ей можно было поведать тайные надежды и устремления, твердо зная, что она немножко пошутит, если это глупость, и поддержит, если это интересно и имеет смысл. Влияние Веры Вениаминовны на мою судьбу и исследования огромно. В.В. с первых минут нашей встречи, когда я была еще студенткой, восприняла меня как личность. Затем, последующие 15 лет, неизменно излучала доброжелательность, терпение и любовь, дарованные ей от Бога, и помогла мне обрести себя в науке.

\section{Встреча с Верой Вениаминовной - предопределение}

Кажется, моявстречасВ.В.предопределенавсемходомсобытий, связанных с обучением на кафедре генетики и селекции биофака Ленинградского государственного университета (ЛГУ). В конце 1950-х годов кафедра во главе с профессором М.Е. Лобашевым была единственной в Советском Союзе, где студенты могли получить классическое генетическое образование (Инге-Вечтомов и др., 1997). До середины 1960-х в биологической науке сохранялась монополия Т.Д. Лысенко гонителя генетики. Новых учебников по генетике не писали, а если и писали, то им ставили жесткие препоны; старые были сожжены или хранились в спецхранах.

Провидение привело меня на эту кафедру. Всю жизнь я благодарна за это судьбе. Помимо общего курса профессора и ассистенты кафедры читали лекции по частной генетике растений, животных и микроорганизмов, изучали все появляющиеся оригинальные статьи. Лекции содержали новые данные, часто из последних публикаций. Это был труд подвижников: только люди, влюбленные в науку, могли осилить такую нагрузку.
Знаменитый растениевод, сподвижник Н.И. Вавилова Петр Михайлович Жуковский читал нам захватывающий и незабываемый курс «Происхождение культурных растений». Профессор Михаил Ефимович Лобашов преподавал общую классическую генетику. Он освещал историю генетических школ Москвы и Ленинграда, которые процветали до разгрома после известной сессии ВАСХНИЛ в августе 1948 года. Именно на этих лекциях я впервые услышала о Вере Вениаминовне Хвостовой. В 1930-е годы она работала в Институте экспериментальной биологии, возглавляемом Н.К. Кольцовым. Будучи аспиранткой Н.П. Дубинина, В.В. выполнила выдающееся цитогенетическое исследование влияния эффекта положения гена cubitus interruptus у дрозофилы. Открытие вошло в историю генетики вместе с именем автора, ставшим авторитетом в цитогенетике.

После разгрома классической генетики в СССР вместе с творцами науки были забыты или утрачены не только знания, но и методики. Особенно пострадала цитогенетика, ибо в ней, как в никакой другой области генетики, важно не только смотреть в микроскоп, но и понимать увиденное. Необходимы непосредственные контакт и передача накопленного опыта от учителя к ученику. В 1961 году мы, студенты третьего курса, специализировавшиеся на генетике растений, напрямую столкнулись с этой проблемой. Перед нами была поставлена задача изучить мейоз у полиплоидной ржи (Secale cereale L.), которую создал на кафедре опытный генетик и селекционер Василий Сергеевич Федоров, ученик Н.И. Вавилова. В.С. Федоров читал нам прекрасный курс по генанализу и учил постигать суть менделизма (Захаров-Гезехус, 2018).

Нам пришлось эмпирически устанавливать фазу развития колосков диплоидных растений ржи, содержащих пыльники с клетками на разных стадиях мейоза, а также осваивать методику приготовления временных препаратов. Светлана Соснихина, Михаил Голубовский и я занимались этим все лето. Мы приносили в поле на петергофской базе университета микроскоп, предметные и покровные стекла со спиртовкой и ацето-карминовым красителем, готовили временные препараты и там же смотрели их под микроскопом. Какое было счастье, когда, наконец, удалось найти колоски со всеми стадиями мейоза и увидеть под микроскопом цикл мейоза от профазы до тетрад прямо в поле. Вместе с нами испытывали радость наши наставники В.С. Федоров (руководитель дипломных работ) и генетик Виктор Георгиевич Смирнов (прошел стажировку в США, читал сложный спецкурс цитогенетики и был правой рукой Василия Сергеевича). Я на всю жизнь полюбила мейоз, его гармонию и совершенство, и была заинтригована, как воз- 
никают синхронность деления всех клеток и порядок смены стадий.

Катализирующим событием оказался приезд Ии Ивановны Кикнадзе в альма-матер - на кафедру генетики и селекции лгу - в феврале 1962 года. Бывшая студентка ныне заведовала лабораторией цитологии в новом Институте цитологии и генетики СО АН в Академгородке под Новосибирском. Городок и Институт еще вовсю строились, но первые эшелоны ученых из лучших научных учреждений СССР уже формировали свои команды. Ия Ивановна приехала из Академгородка в Ленинград с важной миссией: заинтересовать выпускников кафедры генетики и селекции поехать в центр науки в Сибири. Она с таким энтузиазмом рассказывала об Академгородке и о возможностях для молодых стажеров, что у нас с мужем Мишей загорелись глаза и мы дали свое согласие (тем более что в Академгородке молодым семьям предоставляли отдельное жилье). Услышав, что я хочу работать в области цитогенетики растений, И.И. Кикнадзе радостно воскликнула: «Инна, вам повезло. Вера Вениаминовна Хвостова ищет нового сотрудника для исследований по цитогенетике пшениц». «Хвостова! - произнесла я. - Об этом можно только мечтать». Ия Ивановна дала мне номер телефона и московский адрес В.В. и посоветовала немедленно с ней связаться.

\section{Мостик, связующий судьбы}

Начну с нашей первой встречи. Я написала письмо В.В. о своем желании изучать мейоз у растений. В ответном письме она подтвердила нужду в кадрах и пригласила меня на свой доклад на конференции по генетике и селекции растений, который состоялся осенью 1962 года во Всесоюзном институте растениеводства (ВИР) в Ленинграде. Темой ее сообщения стали новейшие достижения в цитогенетике отдаленных гибридов злаков. В.В. пообещала поговорить со мной после доклада. Я с нетерпением ждала конференции. Прослушав доклад В.В., была сражена ее логикой, ясностью мысли и качеством иллюстраций. Мне стало ясно - здесь моя судьба.

В перерыве после доклада В.В. обступили сотрудники ВИР и других институтов, забросав вопросами. Было видно - все хорошо ее знают, восхищены ее исследованиями геномного анализа таких сложных отдаленных гибридов, как пшенично-ржаные (тритикале) и пшенично-пырейные гибриды. Вера Вениаминовна вместе с московскими сотрудниками фактически возрождали в стране цитологический и геномный анализ пшеницы и ее отдаленных гибридов. Цитогенетические подходы были утрачены в России с разгромом школ Г.Д. Карпеченко и Г.А. Левицкого. Слушатели долго не отпускали В.В. после доклада. Но дошла очередь и до меня. Смущаясь, я подошла к В.В. со словами: «Я и есть Инна, мечтаю с вами работать». Доброта и свет исходили из ее ласковых лучистых голубых глаз. Меня совсем не удивило, что В.В. повела со мной беседу, как будто мы знакомы всю жизнь. Она рассказала о новых публикациях по амфидиплоидам у злаков, хлопчатника и пасленовых культур. Мы уже начали обсуждать план моей работы в ее лаборатории, и я вдруг осознала, что у меня впереди еще год до защиты диплома в университете. «Ну и что же, - сказала В.В. -
Вы и не заметите, как пролетит время. Я хочу, чтобы вы думали в этом направлении, читали и подготовили себя». На этой ноте мы дружески расстались с обещанием держать эпистолярную связь.

\section{Приезд в Академгородок}

В августе 1963 года после окончания ЛГУ мы с мужем Михаилом оказались в Академгородке. На въезде в него было начертано «Российское могущество прирастать будет Сибирью...» Молодежь Академгородка искрилась энергией. Оптимизм и культ науки составляли атмосферу повседневной жизни. Коллектив городка был молод и состоял в основном из энтузиастов, выпускников лучших учебных заведений страны. Все равны, никакого чинопочитания, уважение к учителям и общая идея и цель - прогресс науки. Из писем Веры Вениаминовны я знала, что пока она останется в Москве. Ей было нужно время довести аспирантов до защиты диссертаций и передать московскую лабораторию в надежные руки. Она будет наведываться в Новосибирск периодически, а в ее отсутствие мы, сотрудники, будем находиться под опекой И.И. Кикнадзе - заведующей лабораторией общей цитологии (Захаров и др., 2010).

В 1963 году в группе В.В. было всего трое исследователей: Алла Лункина, Фатима Шкутина, на год раньше меня окончившая кафедру генетики и селекции лгу, и я. Меня приняли вместо цитолога Галины Ячевской, которая незадолго до моего приезда перешла в Московский НИИСХ «Немчиновка» - центр селекции и семеноводства зерновых культур центральных районов Нечерноземной зоны России. Г.Л. Ячевская стала нашим связующим звеном с создателями отдаленных гибридов злаков, известными селекционерами В.Е. Писаревым и Г.Д. Лапченко. Она работала непосредственно с Г.Д. Лапченко и восхищалась его неутомимой энергией и преданностью своему селекционному творению - пшенично-пырейным гибридам (Лапченко, 1967).

Мы, трое сотрудников будущей лаборатории цитогенетики растений, подружились и дорожили нашим мини-коллективом. Как мы ожидали приездов Веры Вениаминовны! Возможность общения с ней, обсуждения результатов и планов на будущее делала ее приезды праздниками. Вера Вениаминовна привозила новые сведения в области цитогенетики отдаленных гибридов злаков, рассказывала о новых методах и находках в генетике высших растений.

\section{Эпизод из исследований \\ отдаленных гибридов злаков}

Вера Вениаминовна была перфекционистом, особенно в оформлении и демонстрации результатов опытов. Она хотела, чтобы мы следовали ее критериям в практике. Однажды она привезла фото, подаренное ей Галиной Ячевской, - кариотип из 28 бивалентов метафазы I пшенично-пырейного гибрида $(2 n=8 x=56)$. Биваленты были отчетливо видны и легко могли быть рассчитаны даже непрофессионалом. Мы с Фатимой ахнули от восторга. Как же это совершенство было достигнуто? В.В. рассказала о новой методике фиксации колосков злаков: пропионовая кислота, заменяя уксусную, резко улучшает качество препаратов. Хромосомы не собираются в клубок, а лежат отдельно, облегчая их 
подсчет и анализ в клетке. Мы кинулись в отдел снабжения заказывать этот химикат. Оказалось, заказать его можно, но получить - только в следующем году. Вернулись сокрушенные и разочарованные и поделились с В.В. Она успокоила: «Не волнуйтесь, девочки. В этом году я обязательно приеду в городок ко времени фиксации материала и привезу вам бутылку пропионовой кислоты». Вера Вениаминовна привезла нам пропионку как раз вовремя. Однако все ее вещи и чемоданчик были непоправимо испорчены. Мы очень сокрушались вместе с ней, но первые же препараты, приготовленные с помощью нового метода, заставили В.В. забыть все огорчения. Мы не могли нарадоваться на метафазные пластинки 56-хромосомных амфидиплоидов - так хороши они были и так легко их было анализировать.

\section{Вера Вениаминовна в Академгородке}

В 1966 году Вера Вениаминовна, наконец, переехала в Академгородок. Она со всей энергией и энтузиазмом включилась в работу лаборатории. Были приняты новые сотрудники: Екатерина Борисовна Будашкина, Антонина Ивановна Щапова и Клавдия Кузминична Сидорова. В это же время на должность препаратора мне в помощь зачислили Валентину Горбачеву, тогда 17-летнюю застенчивую девочку. Она стала моей незаменимой помощницей, ни минуты не могла сидеть без работы, всегда правдива и сопровождала меня во всех экспедициях.

Вера Вениаминовна полностью погрузилась в ход наших исследований. Мы обсуждали каждую деталь, вместе рассматривали трудно интерпретируемые картины гибридных кариотипов, особенно характер синапсиса хромосом. Задача состояла в умении научиться понимать увиденное под микроскопом. Опыт и эрудиция В.В. очень помогали. Многое для нашего понимания дал детальный анализ работ и публикаций знаменитых в то время цитогенетиков пшениц - Эрнеста Сирса (США) и Ральфа Райли (Великобритания). К тому времени Э. Сирс завершил классификацию всей 21 хромосомы гексаплоидной мягкой пшеницы (Triticum aestivum L.) по трем ABD-геномам. Он определил, что хромосомы этой пшеницы распределяются по семи гомеологичным группам, по три хромосомы в каждой (1A, 1B, 1D ...7A, 7B, 7D), по одной от каждого генома. Помимо теоретического вклада огромной важности Э. Сирс разработал основы изучения генетики и цитологии пшеницы. Искусными методами хромосомной инженерии он создал серии анеуплоидных линий: нуллисомики $(2 n=40)$, моносомики $(2 n=41)$, трисомики $(2 n=43)$ и тетрасомики $(2 n=44)$ - по каждой из 21 хромосомы мягкой пшеницы! Кроме того, сконструировал серии линий-телоцентриков $(2 n=40+2 \mathrm{t})$ по обоим плечам всех хромосом. Тем самым Э. Сирс фактически создал набор хромосом - специфичных маркеров пшеницы (как ныне делают в молекулярной цитологии и генетике). Тогда это было особенно важно цитогенетикам (Sears, 1954). Я с удовольствием штудировала все эти нелегкие для понимания, но прекрасные цитогенетические эксперименты.

Гексаплоидная пшеница ведет себя в мейозе как диплоидная, образуя 21 бивалент в метафазе І. Такое поведение гомологов оказалось под контролем хромосомы 5В. Эффект запрета на гомеологичную конъюгацию 5В-хромосомой был независимо и одновременно открыт Райли и Сирсом в 1958 году. При отсутствии 5В-хромосомы этот запрет снимается, и гомеологи включаются в конъюгацию наравне с гомологами. В результате кроме бивалентов появляются уни- и мультиваленты (Riley, Chapman, 1958; Sears, Okamoto, 1958). Позднее была найдена мутация, $\mathrm{Ph} 1$, которая контролирует конъюгацию хромосом у полиплоидных пшениц. Она оказалась делецией в длинном плече хромосомы 5В размером в 60 Мб. Ее появление облегчило работу исследователей, заменив использование нуллисомиков по 5В (Sears, 1977).

С этого момента английские цитогенетики стали досконально исследовать функцию Ph1-локуса хромосомы 5В на мейоз у мягкой пшеницы, ее сородичей и отдаленных гибридов между ними. Поток работ (одна интереснее другой) захлестывал журналы по генетике растений. Мы в лаборатории старались не пропустить ни одной публикации. B.В. живо интересовалась достижениями в этом направлении и обычно спрашивала нас с Фатимой: «Ну, что вы прочли новенького?» И светилась радостью, если мы показывали очередной номер журнала с новой статьей лаборатории Райли или других авторов (Feldman, 1968; Wall et al., 1971; Riley, 1974). Анализ работ и методов ведущих цитогенетиков пшениц, их сопоставление с собственными исследованиями цитогенетики октоплоидных $(2 n=8 x=56)$ пшенично-ржаных и пшенично-пырейных гибридов, курирование Веры Вениаминовны помогли нам стать грамотными цитогенетиками.

Позднее, к 2000 году, молекулярную природу Ph1-локуса стали изучать в лаборатории Грэма Мура в Великобритании (John Innes Centre, Norwich Research Park). Оказалось, что Ph1-локус, расположенный в длинном плече хромосомы 5В ближе к теломерному концу, содержит кластер из семи вариантов cdk-типа генов (суclin-dependent kinase), между которыми внедрена вставка субтеломерного гетерохроматина. $C d k$-гены пшеницы по молекулярной структуре ближе всего (гомологичны) Cdk2-гену млекопитающих, хорошо изученному у человека. Cdk2-ген контролирует преобразование хроматина при репликации и конформацию гетерохроматина. Функции Cdk2-гена и Ph1-локуса сходны особенно в эффекте на репликацию, конформацию хроматина и рекомбинацию (Griffiths et al., 2006; All-Kaff et al., 2008; Greer et al., 2012). Работы в этом направлении продолжаются до сих пор, ученые все же надеются выделить Ph1-ген. Проведено успешное физическое картирование короткого плеча хромосомы 5В. В настоящее время сотрудники лаборатории Елены Салиной в ИЦиГ СО РАН активно включены в изучение молекулярной сущности ДНК хромосомы 5В (Sergeeva et al., 2014). Продолжение этого исследования для длинного плеча хромосомы 5B, в котором расположен локус $P h 1$, возможно, позволит понять особенности его молекулярной структуры (Salina et al., 2018).

\section{Совместные поездки}

на конференции и симпозиумы

Незабываемы совместные поездки на конференции: дватри дня в поезде по маршруту Новосибирск - Москва - Ленинград - Киев и обратно. Мы обычно размещались в одном купе, и три дня общения с Верой Вениаминовной были га- 
рантированы. О себе она не любила говорить, но о коллегах и совместных исследованиях могла рассказывать долго. Мы готовы были слушать ее бесконечно - под умиротворяющий перестук колес и перекличку гудков. Как она любила и уважала своих учителей и друзей-коллег молодости! Только несколько имен: Н.К. Кольцов, А.С. Серебровский, В.В. Сахаров, Н.П. Дубинин, Н.Н. Соколов, Б.Н. Сидоров, И.В. Паншин. Восхищение и гордость за судьбу, которая свела ее с такими талантливыми и интересными людьми, рефреном звучала в ее воспоминаниях. Многое мы узнали и о невзгодах, выпавших на долю генетиков, друзей и соратников Веры Вениаминовны, в годы лысенкоизма. Думаю, взаимное уважение, сочувствие и преданность друг другу старшего поколения ученых помогли быстрее восстановить классическую генетику в России после снятия Н.С. Хрущева и монополии Т.Д. Лысенко в 1964 г. Из этих бесед сложился образ нашего наставника как многосторонне образованной личности, влюбленной в науку, хорошо знающей языки, литературу, музыку, живопись и театр.

\section{Защита и опора}

Веру Вениаминовну интересовали все сферы жизни сотрудников. Любящая бабушка, она была неравнодушна к нашим детишкам, всех знала по именам и, навещая, не забывала о подарочках. Помню восклицания нашей меньшенькой дочки Юлечки: «Мама, мама, Вера Миновна пришла с гостинцами».

В.В. была доброжелательная и справедливая, но и строгая. В 1968 году меня выбрали в детский сектор в местком ИЦиГ. Местком СО АН СССР обделял Институт местами в детских садах и яслях. Меня попросили поработать в этом направлении, и, конечно, я немного увлеклась, относясь к этим обязанностям серьезно. Ходила в «большой» местком на все заседания комиссии по распределению мест в детсадах с длинным списком нуждающихся в них детей сотрудников ИЦиГ. В итоге проблему удалось сдвинуть с места: к концу года мне предложили поработать в детской комиссии «большого» месткома. Такая общественная нагрузка отнимала бы гораздо больше времени, но, не желая обижать коллег моментальным отказом, я ответила, что посоветуюсь с руководителем.

Рассказав В.В. о полученном приглашении, по выражению лица я поняла, что она не одобряет эту затею. Вера Вениаминовна поинтересовалась, что меня связывает с месткомом. «Только получить больше мест в садиках для наших детей», - отчеканила я, не задумываясь. В.В. ответила: «Оставьте эти глупости! Вы человек увлеченный наукой, у вас все хорошо получается. Оставьте это тем, кто ищет другой путь в жизни. Вы его нашли и следуйте ему. И не дурите, Инна, не огорчайте меня». Этот урок я запомнила на всю жизнь и очень благодарна моему учителю. Оберегла от суеты сует.

Второй случай оказался решающим в моей научной судьбе. Это произошло в октябре 1970 года после защиты кандидатской диссертации по цитогенетике пшенично-пырейных гибридов. Думаю, у каждого ученого возникают вопросы, что делать дальше и куда идти. Желая обсудить тематику моих будущих исследований, Вера Вениаминовна посове- товала продолжать работать с отдаленными гибридами, у которых множество неразрешенных проблем. Я ждала этого разговора и была рада, что В.В. сама подняла эту тему.

Несомненно, цитогенетика отдаленных гибридов была хорошей школой познания мейоза. Многие типы аномалий мейоза, которые встретились у таких генетически сложных объектов, были мной изучены. В 1971 году под редакцией В.В. Хвостовой и П.М. Жуковского вышла книга «Цитогенетика пшениц и ее гибридов». В наших статьях, опубликованных в этой коллективной монографии, были подведены итоги семилетней работы лаборатории с отдаленными гибридами злаков. Мы определили, что основной причиной низкой плодовитости октоплоидных гибридов по сравнению с мягкой пшеницей являются аномалии мейоза. Даже у лучших, селектированных на высокую плодовитость гибридов аномалии мейоза колебались от 15 до 30\%, следовательно, отдаленные гибриды можно использовать лишь как доноров генов желаемых признаков (холодоустойчивость, устойчивость к болезням, засухе, ранним заморозкам и т. д.) (Голубовская, 1971).

Для меня погружение в цитогенетику Ph1-локуса и его регуляторного действия на поведение хромосом в мейозе послужили стимулом для будущего поиска и систематического исследования других генов мейоза. Как оказалось, зная функции одного гена, можно управлять синапсисом хромосом и их рекомбинацией, целенаправленно получая транслокации между хромосомами пшеницы и ее сородичами. Эти размышления и определили выбор направления моих будущих исследований.

\section{Моя программа: поиск и анализ генов, контролирующих мейоз у растений}

Мне стало ясно, что без знания генетического контроля мейоза нельзя понять и преодолеть причины нарушений мейоза у амфидиплоидов. Я думала о мейозе как об универсальном генетически контролируемом процессе. Какие гены контролируют два деления мейоза от начала до окончания? Каковы ключевые события мейоза, в какой последовательности они совершаются и взаимодействуют друг с другом?

Я наметила для себя долговременную задачу систематического поиска и цитогенетического анализа мейотических мутантов (мей-мутантов). Для задуманного проекта следовало выбрать подходящий модельный объект с хорошей генетикой и цитологией. Таким объектом среди растений я видела только кукурузу (Zea mays L.): этот вид начиная с 1910-х годов лучше всех изучен среди высших растений. Кукуруза в равной степени и перекрестник, и самоопылитель, поэтому можно было получать и работать на чистых линиях. Я мечтала создать коллекцию разных мейотических мутантов и заняться их детальной цитогенетикой. Таковы были мои дерзкие устремления и планы на будущее. Конечно, я нервничала, озвучивая их Вере Вениаминовне. Меня одолевали сомнения, поддержит ли меня мой учитель. Вера Вениаминовна выслушала не прерывая и строго сказала: «Инна, вы замахнулись на огромную и интересную, но сложную проблему. Уверены ли вы в успехе? Как вы получите мутанты? Где вы будете выращивать кукурузу? Как вы одна справитесь с такой сложной задачей?» 
Я была готова к таким естественным сомнениям и ответила, что много думала об этом. Мой план - связаться с Михаилом Ивановичем Хаджиновым - блестящим генетиком и селекционером кукурузы, который прошел в 1930-х годах школу Н.И. Вавилова и Г.Д. Карпеченко. Именно ему в 1932 году Н.И. Вавилов доверил вести богатейшую ВИРовскую коллекцию кукурузы и заняться ее генетикой. М.И. Хаджинов - сооткрыватель цитоплазматической мужской стерильности. В его распоряжении было множество линий кукурузы, которые проявляли стерильность и среди которых можно было найти желаемые мей-мутации. В то время Михаил Иванович работал в Краснодарском НИИ сельского хозяйства заведующим отделом селекции и семеноводства кукурузы. Также его отдел занимался радиационным и химическим мутагенезом кукурузы. Вполне вероятно, что среди разных мутантов кукурузы могли быть линии с выщеплением стерильных метелок. Среди них я планировала отыскать и изолировать семьи, стерильность которых определяется аномалиями генов мейоза.

«Главное, - сказала я Вере Вениаминовне, - чтобы в институте мне разрешили выезды в полевые экспедиции в Краснодар и опорный пункт в совхозе «Южные культуры» в Адлере». В те годы совхоз сдавал в аренду поля ИЦиГ для посевов и размножения опытного материала, в основном кукурузы, которая не успевала в условиях короткого сибирского лета давать полноценные семена. В.В. внимательно выслушала мои планы и в целом их одобрила. Она обещала поговорить в дирекции о разрешении и финансировании моих регулярных выездов в Краснодарский край. После просьбы Веры Вениаминовны дирекция ИЦиГ во главе с Дмитрием Константиновичем Беляевым поддержала наши начинания. И все же В.В. была полна сомнений и, я бы сказала, опасений. Конечно, волновалась за меня. Она решила на год не включать в планы лаборатории новую тематику, посоветовав мне дождаться первых положительных результатов. Так родилось новое направление «Генетика мейоза» в лаборатории цитогенетики растений, руководимой В.В. Хвостовой.

\section{В.В. Хвостова и М.И. Хаджинов у колыбели проекта «Генетика мейоза»}

Помощь двух выдающихся ученых и личностей, людей редчайшей доброжелательности и знаний, стала благословением и залогом удачи в рождении и развитии этого нового направления в цитогенетике растений. Я не ошиблась в своих ожиданиях. При первой же встрече в Краснодаре Михаил Иванович полностью одобрил идею проекта и сразу же предоставил для цитологического исследования 50 семей, которые выщепляли стерильные метелки. Материал, накопленный его сотрудниками, был безвозмездно передан мне в руки А.С. Машненковым - бывшим аспирантом и затем сотрудником Хаджинова и моим соавтором. Ровно 50 лет назад, в апреле 1971 года, на полях совхоза «Южные культуры» я сделала первый посев кукурузы для поиска и анализа мутаций с нарушениями мейоза.

Какое это было радостное время и какой замечательный коллектив молодых и талантливых исследователей ИЦиГ работал в то время в экспедиции по генетике и селекции кукурузы! Станислав Малецкий (это была его прекрасная идея создать опорный селекционно-генетический пункт на базе адлеровского совхоза), Владимир и Эмма Шумные, Валерий Семенов, Лена Половинкина, Эмма Денисова, Галина Похмельных - все они, энергичные, увлеченные идеями, помогали мне. Ведь я впервые работала с кукурузой и нуждалась в практических советах, а они уже имели опыт. В следующем сезоне на опорном пункте появились более молодые сотрудники: Женя Левитес, Сережа Вепрев и Наташа Вайсман. Приятно вспоминать наши вагончики в поле и замечательный товарищеский настрой экспедиции. Женя Левитес, открытая душа, помогал в любой ситуации. Зеленоглазый добродушный насмешник Сережа Вепрев и погруженная в себя и музыку Наташа Вайсман тоже были надежными и добрыми коллегами.

Мне повезло: в первом же сезоне работы на опорном пункте из 50 семей кукурузы удалось найти и изолировать 13 мутантов с нарушенным мейозом. Потом я работала на полях Краснодара (КНИИСХ). Михаил Иванович Хаджинов, святой человек, помогал спасать мутанты от засухи. Он (уже тогда академик ВАСХНИЛ, заслуженный селекционер и вице-президент ВОГиС) самолично приезжал на лошаденке и подвозил к моим крошечным по сравнению с необъятными кукурузными полями Института делянкам бочку с водой. И пока я поливала из шланга увядающие от засухи растения, Михаил Иванович расспрашивал о фенотипах новых мей-мутантов, с интересом слушал об их цитологии и подбадривал меня. Так была проложена моя тропа в неизведанную область систематического поиска и цитогенетического анализа мей-мутантов. Вера Вениаминовна поддерживала меня во всех начинаниях, и загадки, которые выкидывали мутанты, мы решали вместе.

Вера Вениаминовна была экспансивной натурой. Увидев красивый препарат с необычной конфигурацией хромосом, расшифрованной нами, она моментально возбуждалась и спешила поделиться радостью с друзьями и молодыми коллегами. Всех собирала вокруг микроскопа и с жаром показывала и объясняла видимое на слайдах. Природный педагогический дар ярко проявлялся даже в повседневной исследовательской работе. Бескорыстная, вникающая в мелочи лабораторной жизни, В.В. всегда была рада любому нашему успеху.

\section{Загадка гена afd1: блок первого деления мейоза.} Гетерохрония и эволюционный консерватизм

Расскажу о ходе цитологического анализа лишь одного удивительного мей-мутанта, моего фаворита. Этот мутант я обозначила как afd1 (the absence of the first division). Сейчас мне трудно вновь пережить состояние настроя души того далекого времени. Теперь загадка фенотипа мутанта кажется такой ясной. Как же я сразу не догадалась?

Исследуя процесс мейоза у мутанта afd1, я долго ломала голову над тем, что же я вижу под микроскопом. А видела я следующее: при отсутствии характерных для мейоза стадий профазы I (лепто- и пахитены) все хромосомы были сплетены в плотный клубок. Столь обычная для нормального мейоза конъюгация гомологичных хромосом полностью отсутствовала. Однако на стадии диакинеза все хромосо- 

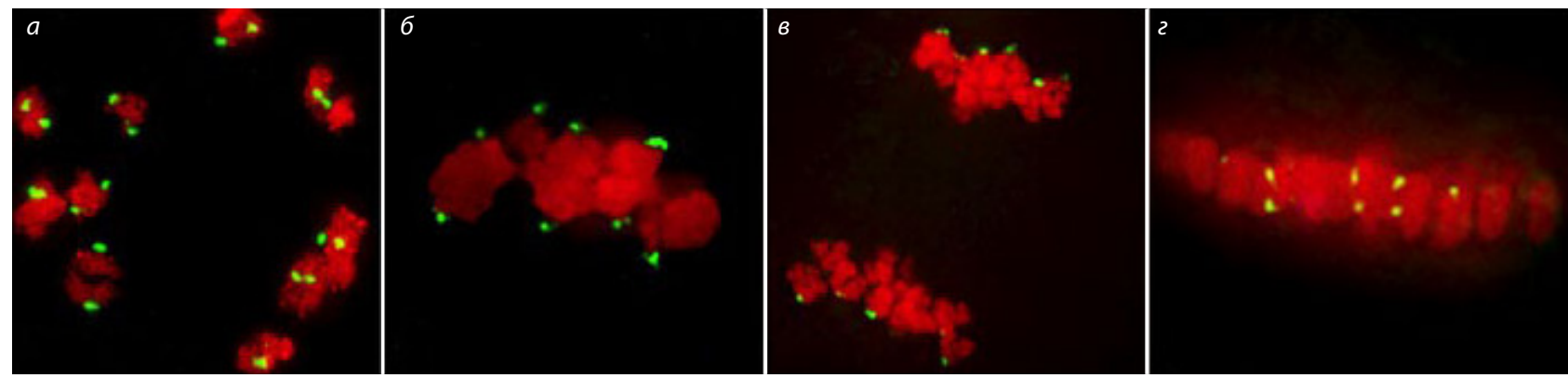

Рис. 1. Мейотические клетки кукурузы в первом делении мейоза в норме $(a, 6,8)$ и у afd1-мутанта (2). Флуоресцентная окраска: хромосомы (DAPI) отмечены красным цветом, центромеры (FITC) - желтым

$a$ - диакинез, 10 бивалентов и реплицированные центромеры хромосом в виде двойных точек; 6 - метафаза І, метафазная пластинка и центромеры каждого бивалента ориентированы к противоположным полюсам; в - анафаза І, правильное редукционное расхождение гомологичных хромосом 2-afd1-мутант, метафаза I, 20 хромосом образуют метафазную пластинку, и их сестринские хроматиды ориентированы центромерами к противоположным полюсам. Эквационное митотическое деление заменило редукционное

мы неожиданно визуализировались в виде 20 унивалентов и совершенно непредсказуемо в метафазе I вместо случайного разброса по клетке 20 унивалентов хромосомы в виде колечек, похожих на биваленты, выстраивались в одну линию в центре клетки. Они формировали метафазную пластинку с центромерами, ориентированными к противоположным полюсам. В анафазе I мейоза хромосомы без редукции расходились 20 + 20 между двумя полюсами. Диады, продукт мейоза I, не отличались от диад нормального мейоза.

Первое, что пришло на ум наблюдая под микроскопом данный парадокс, - это феномен полиплоидии за счет возможной премейотической репликации хромосом в ходе дифференциации премейотических клеток. Однако подсчеты числа хромосом в клетках тапетума (они имеют то же происхождение, что и мейотические клетки) и клетках тканей пыльника показывали нормальное диплоидное число в 20 хромосом. Полиплоидия исключалась.

Мои коллеги, а также Вера Вениаминовна и Ия Ивановна Кикнадзе видели препараты этого загадочного мутанта всех смущало отсутствие конъюгации гомологов и в то же время упорядоченное расхождение хромосом в анафазе I с нормальными диадами после первого деления мейоза. Оставалось неясным, откуда вместо ожидаемых 10 бивалентов взялись 20 кольцеобразных хромосом, похожих на биваленты. Озарение осенило меня среди глубокой ночи. Я не могла дождаться утра и сразу поспешила рассказать о возможном решении загадки В.В. «Эврика! Я поняла! - воскликнула я, врываясь в маленький закуток на третьем этаже у лифта, бывший временным пристанищем В.В., и выпалила возбужденно: - У afd1-мутанта нет редукционного деления, оно заменено эквационным делением, похожим на митоз». Рис. 1 подтверждает это предположение.

Если гипотеза верна, то все увиденное под микроскопом легко объяснимо. Мистические 20 хромосом в метафазе I, образующие в центре клетки метафазную пластинку, - это хромосомы, которые не вступили в синапсис со своими гомологами и миновали редукцию числа хромосом - непременное условие первого мей-деления. Преждевременное расхождение центромер сестринских хроматид в анафазе объясняет их кольцеобразную форму. Сестринские хроматиды ориентированы центромерами к противоположным полюсам. Натяжение, создаваемое нитями веретена, придает им форму вытянутых колечек. В норме же это событие происходит только в анафазе второго деления.

Убедительным критерием проверки правильности гипотезы могло быть сравнение структуры хромосом нормы и afd1-мутанта во втором делении мейоза. В норме хромосомы в профазе второго деления сохраняют Х-образную структуру. Профаза II удобна для изучения, хромосомы не так сильно спирализированы и достаточно протяженные. Каждая хромосома состоит из двух сестринских хроматид, которые удерживаются вместе только в районе центромер. Подобная структура сохраняется вплоть до расхождения центромер сестринских хроматид в анафазе II. Если гипотеза правильная и у afd1-мутанта центромеры сестринских хроматид преждевременно разошлись в первом делении мейоза, то ожидается, что все 20 хромосом профазы II будут представлены одной хроматидой. Действительно, хромосомы afd 1-мутанта в профазе II представляли собой отдельные хроматиды. Гипотеза подтвердилась.

Чтобы исключить возражение, что любая унивалентная хромосома ведет себя как у afd1-мутанта, я исследовала хромосомы профазы II другого найденного десинаптического мей-мутанта dsy1 (desynaptic1). При значительно нарушенной конъюгации хромосом в MI сохранялся нормальный редукционный характер их расхождения. Как же я обрадовалась, когда увидела, что хромосомы нормальных растений и хромосомы десинаптического dsy1-мутанта в профазе II неотличимы и состоят из двух хроматид, соединенных центромерой. Мутант afd1 уникален! У него нарушены два ключевых события мейоза: нет редукции числа хромосом и центромеры сестринских хроматид преждевременно расходятся в анафазе І. Подобный феномен называется «гетерохрония» - преждевременное или более позднее, чем в норме, действие гена. Гетерохрония хорошо известна в генетике развития и возникает, когда нарушается нормальное расписание работы генов. Для нормального 
онтогенеза каждый ген должен действовать в данное время, в данном месте и с данной экспрессивностью.

Приготовив все препараты и микроскоп, я снова пришла к Вере Вениаминовне, попросив посмотреть препараты и послушать мою интерпретацию. В.В. все бросила, и мы поторопились к микроскопу. Когда Вера Вениаминовна увидела у afd1-мутанта одиночные хроматиды во множестве клеток профазы II, а у нормы и dsy1-мутанта двухроматидные хромосомы, вся просияв, она с облегчением вздохнула и сказала: «Поздравляю, Инна, вы молодец. Все логично объясняется, и все встает на свои места. Неординарный, уникальный феномен. Скорее нужно подготовить публикацию об afd1мутанте».

Написав текст и собрав иллюстрации, я принесла материал на редакцию Вере Вениаминовне (без ее одобрения и редактирования мы в лаборатории ничего не публиковали). Через несколько дней В.В. возвратила мне отредактированный текст и сказала: «Я вычеркнула свое имя из списка авторов. Инна, это ваша работа, вы все сделала сама, и я к этому не имею никакого отношения». Я очень расстроилась: «Вера Вениаминовна, это не так. Без ваших советов и помощи, наших обсуждений каждой детали я бы не пришла к правильным выводам. Я не мыслю этой публикации без вас. Пожалуйста, останьтесь соавтором. Если я что-то сделала не так, я согласна на любые исправления или дополнительные данные». Вера Вениаминовна ответила: «Инна, с отдаленной гибридизацией вы работали над проблемами, которыми я руководила, и вела вас за собой. Проблема генетики мейоза и коллекция мей-мутантов - ваш выбор, стратегия и толкование наблюдений. Да, я помогаю вам, участвую в обсуждениях и даю советы по литературе и методикам. Но это мой долг заведующего лабораторией. На этом и кончим. Я буду вас поддерживать всегда, но не ставьте меня в ваши статьи. Мне своей славы хватает, чужая не нужна». Так раз и навсегда она решила эту проблему вопреки моим желаниям. Я очень огорчилась: быть соавтором учителя всегда было большой гордостью для меня. Но ее «нет» не подлежало обсуждению - мы в лаборатории это все знали. Так была опубликована информация о мутанте afd1 (Голубовская, Машненков, 1975).

Много ли мы встречали на нашем пути таких принципиальных лидеров? А Михаил Иванович Хаджинов, не считающийся со своей занятостью и самолично спасающий коллекцию молодого коллеги из другого института? Не часто увидишь такое сочувствие и сопереживание. Подобные уроки учителей усваиваются на долгие годы лучше, чем наставления или тексты книг.

Позднее, в 2006 году, ген Afd1 был клонирован в лаборатории Зака Канде в Университете Калифорнии (Беркли), с которой я сотрудничала много лет. Afd1-ген оказался ортологом гена дрожжей Rec8, кодирующего REC8-белок (класса альфа-клейзинов) - разновидность белков когезинов. Этот ген широко распространен у высших и низших организмов: человека, мыши, таких растений, как арабидопсис и рис, червей Caenorhabditis elegans Maupas, грибов Sordaria macrospora Auersw и дрожжей. У всех организмов белок REC8 выполняет одну и ту же функцию: удерживает вместе сестринские хроматиды до их расхождения в анафазе II.
B первом делении мейоза REC8-белок локализуется по всей длине хроматид, но после завершения первого деления сохраняется только в районах центромер, освобождая плечи хромосом. REC8 исчезает после All, когда сестринские хроматиды разошлись. Этот белок критически важен для осуществления редукции числа хромосом - основной функции мейоза, поэтому ген Rec8 влияет на все события первого деления мейоза: синапсис гомологов, рекомбинацию, расхождение гомологичных хромосом в анафазе I и центромеров сестринских хроматид в All. При этом стоит отметить, что только у двух столь разных объектов, как кукуруза и дрожжи Schizosaccharomyces pombe Lindntr, при мутациях этого гена происходит преждевременное расхождение центромеров сестринских хроматид в анафазе I мейоза вместо анафазы II (Kitajima et al., 2003; Golubovskaya et al., 2006).

\section{Концепция генетического контроля мейоза}

К началу 1970-х годов, когда выяснилось, что одни и те же контролируемые генами белки и ферменты могут принимать участие в разных общегенетических процессах, связанных с функцией и поведением ДНК - ее воспроизведением, обменом участками (рекомбинацией), репарацией повреждений в ходе конъюгации хромосомных нитей, их расхождением в дочерние клетки, интерес к мейозу резко возрос. Одновременно с поиском и анализом мутантов мейоза у кукурузы я собрала и проанализировала литературу по мутациям, нарушающим мейоз у дрожжей, насекомых, растений и животных, опубликованную к 1970 году, для написания концептуального обзора. Анализ фенотипов мутаций, нарушающих ход мейоза у разных организмов, привел меня к выводу, что можно выделить по крайней мере семь ключевых этапов мейоза, которые находятся под контролем отдельных генов: запуск или переключение клеточного деления с митоза на мейоз; попарное сближение и синапсис гомологичных хромосом; обмен сегментами гомологичных хромосом или рекомбинация - образование хиазм; расхождение гомологов; инициация второго деления и собственно разделение клетки надвое (цитокинез). Концепцию генетического контроля мейоза я впервые изложила в статье «Генетический контроль поведения хромосом в мейозе» в книге «Цитология и генетика мейоза» (1975), изданной в Москве под редакцией В.В. Хвостовой и Ю.Ф. Богданова, и позднее в двух международных сводках по цитологии и генетике: International Review Cytology (1979) и Advances in Genetics (1989). В это время Веры Вениаминовны уже не было с нами.

Поиск и анализ мей-мутаций я продолжила и после переезда в 1986 году в Ленинград. В отделе генетики растений ВИРа, возглавляемом Б.В. Ригиным, у меня появились собственная группа и аспиранты. Здесь я заказала семена всех шести мейотических мутантов, поддерживаемых с 1930-х годов Генетическим центром мутантов кукурузы в Иллинойсе (США). Выполнив тест на аллелизм с моими мутациями, я получила неожиданные результаты: моя мутация pra1 (the prophase arrest1) оказалась новым аллелем хорошо известного гена ameiotic1 (am1), изолированного виднейшим цитогенетиком кукурузы М. Родсом в 1956 г. Указанный факт стал критическим для уточнения функции этого уникаль- 


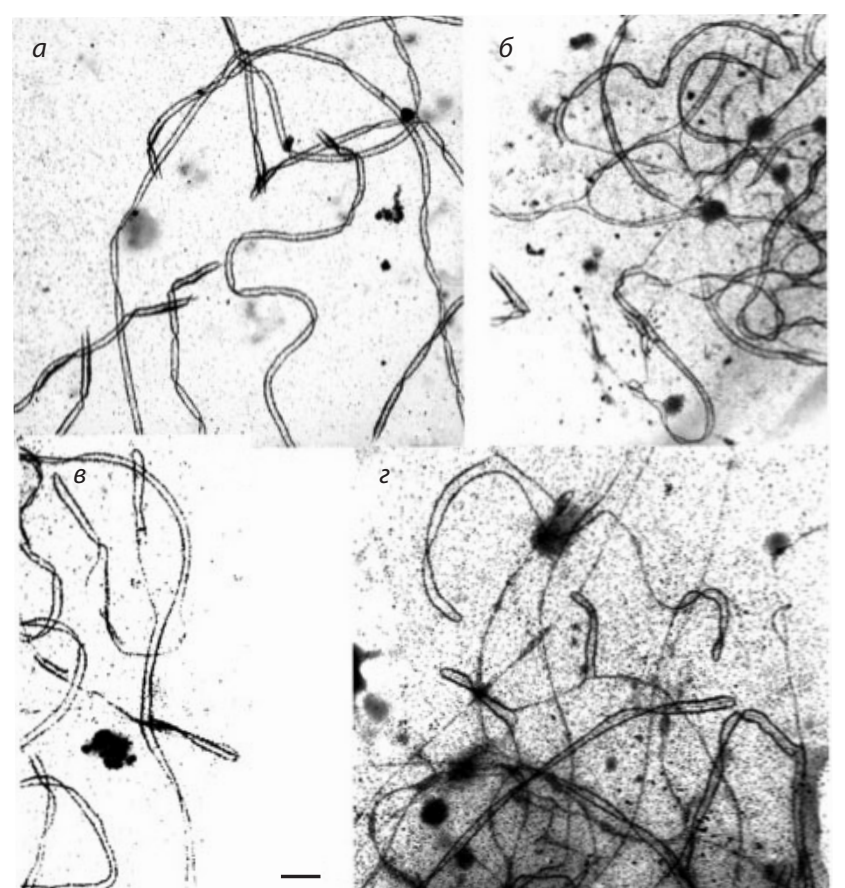

Рис. 2. Электронная микроскопия клеток в профазе I (фрагменты). Синаптонемальный комплекс представлен в пахитене мейоза в норме и у трех разных мутантов кукурузы. Увеличение 1 мкм

$a$ - нормальная клетка: два латеральных элемента комплекса представленной пары гомологичных хромосом следуют параллельно гомологичный синапсис; 6 - клетка dsy1-мутанта: синаптонемальный комплекс выявляет частую смену партнеров спаривания - негомологичный синапсис; в - клетка mtm99-25-мутанта: участки хромосом складываются в виде шпилек (foldback) - негомологичный синапсис; г - клетка as 1-мутанта: шпильки хромосом разных размеров, иногда вся хромосома складывается пополам

ного гена в инициации мейоза. В дальнейшем изучение ameiotic1-мутанта вылилось в прекрасную диссертационную работу аспирантки Зинаиды Гребенниковой, защищенную в 1991 году.

Кроме того, моя группа с помощью электронной микроскопии исследовала все мутации с нарушенным синапсисом гомологичных хромосом и выявила различные аномалии в синаптонемальном комплексе - структуре, необходимой для синапсиса хромосом и специфической для мейоза. По конфигурации синаптонемального комплекса можно было судить о характере синапсиса, который полностью отсутствовал или был негомологичным. В этом случае хромосомы часто меняли партнеров спаривания или предпочитали синаптировать сами на себя, образуя шпилькообразные конфигурации комплекса. Типы нарушений синапсиса представлены на рис. 2.

Работая в летние сезоны 1990-1998 годов на полях университета Северной Дакоты (США), я удвоила мировую коллекцию мей-мутантов у кукурузы, используя для мутагенеза линии кукурузы с мобильными генетическими элементами. В общей сложности коллекция составила 36 генов, многие из которых представлены несколькими аллельными вариантами (от двух у dsy1 до пяти - шести у afd 1 и am 1 соответ-

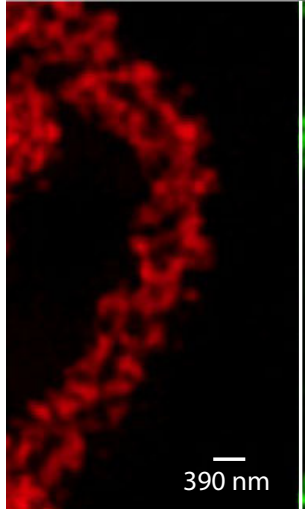

Хроматин DAPI

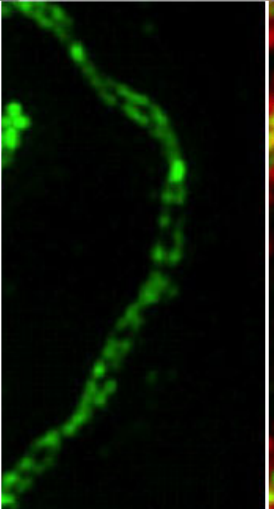

AFD1

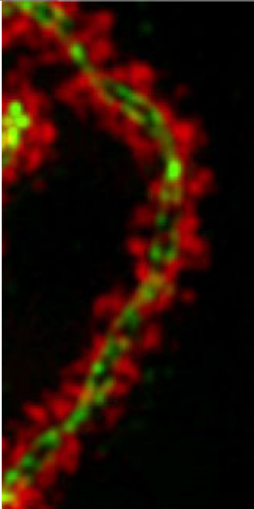

Вместе
Рис. 3. Фрагмент пахитенной хромосомы кукурузы

Для иммунной окраски использованы антитела против AFD1-белка компонента осевых и латеральных элементов синаптонемального комплекса. Хромосома (DAPI) отмечена красным цветом, AFD1-белок зеленым. Белок четко виден в форме скрученной двойной нити. На совмещенном канале белок AFD1 локализован между двумя гомологами

ственно). Гены коллекции охватывали все выделенные мной ключевые события мейоза у кукурузы.

В 1999-2010 годах в отделе клеточной и молекулярной биологии Университета Калифорнии (Беркли) я проводила углубленный молекулярно-цитогенетический анализ коллекции мутантов. Использовала FISH - флуоресцентную in situ-гибридизацию с ДНК-маркерами на тело-, центромерные повторы и 5S-rDNA, а также иммуноокраску с антителами против белков синаптонемального комплекса (ASY1, AFD1/REC8, ZYP1) и белков, принимающих участие в рекомбинации (RAD51, SP011, DMC1). На рис. 3 представлена локализация AFD1-белка в латеральных элементах синаптонемного комплекса пахитенных хромосом кукурузы. Кстати гены, кодирующие перечисленные выше специфичные для мейоза белки, присутствуют и в нашей коллекции и клонированы нами (Golubovskaya et al., 2011).

\section{Педагог}

Вернемся в прошлое. Педагогика было неугасимой страстью Веры Вениаминовны. Еще в Москве В.В. давала много советов по организации в Академгородке новосибирского университета. Она любила преподавание. Это, видимо, наследственный дар. Еще до революции ее отец, Хвостов Вениамин Михайлович, был профессором имп. Московского университета, а мать, Надежда Павловна, в 1906 году открыла в Москве частную женскую гимназию и преподавала в ней русский язык. Приехав в Академгородок, Вера Вениаминовна совместно с Ией Ивановной Кикнадзе активно включилась в создание кафедры цитологии и генетики на факультете естественных наук НГУ.

Программы обучения студентов этого факультета были составлены при ее непосредственном участии. Особое внимание В.В. отдавала большому цитогенетическому практи- 
куму, составленному в союзе с Михаилом Голубовским. Он был ответственен за генетику дрозофилы, а В.В. - за цитогенетику растений. Она не только составила программу, но и вела практические занятия со студентами. Ей очень хотелось видеть, как молодежь сама готовила и анализировала цитологические препараты под микроскопом. Мы, ее сотрудники, тоже косвенно были вовлечены в занятия со студентами, обеспечивая классы готовым фиксированным материалом.

В 1970 году Вера Вениаминовна загорелась идеей включить в практикум для студентов 4-го курса недавно разработанную технику изучения действия мутагенов на хромосомы вида крепис из семейства сложноцветных. Crepis capillaris (L.) Wallr. - вид с тремя парами хромосом $(2 n=6)$, четко отличимых друг от друга по размерам и структуре. Цитологический анализ хромосомных мутаций этого вида позволяет детально изучать влияние доз радиоактивного облучения на повреждение хромосом. Можно визуально определить, на какой стадии клеточного цикла произошли разрывы хромосом и когда воздействие радиацией наносит клетке наиболее повреждающий эффект. Новая цитогенетическая техника, с одной стороны, была способом зажечь интерес студентов и к цитологии, и к познанию действия радиации на живую клетку; с другой - ностальгией В.В. по проблемам, которыми она жила и успешно занималась в Москве до переезда в Сибирь. Эти два фактора, видимо, и были причиной ее страстного желания включить новую методику в практикум.

Однажды Вера Вениаминовна стала увлеченно рассказывать мне о идее практикума и спросила, не хотела бы я помочь. Я ответила, что с радостью подготовлю красивые препараты мейоза и митоза. В.В. поблагодарила, но отметила, что мечтает опробовать методику радиационного мутагенеза на метафазных хромосомах Crepis capillaris. Я согласилась, что это было бы здорово, однако у нас никто этим методом не владел. Тут В.В. сообщила, что она уже договорилась в Москве с Н.П. Дубининым. Его сотрудница Людмила Немцова, асс этой методики, согласна обучить кого-либо из нашей лаборатории осенью после полевого сезона. В.В. попросила меня поехать в Москву и освоить этот метод. От неожиданности я вошла в ступор: с одной стороны, невозможно отказать в просьбе Вере Вениаминовне, с другой - у меня на руках в то время был 5-месячный младенец, совсем еще крошка. Я попросила время подумать. «Инна, я на вас рассчитываю», - сказала В.В. строго, и мы разошлись. Обсудив ситуацию с Мишей, я поняла, что не могу отказаться. Начиналось лето, до осени оставалось пять месяцев - нужно было действовать. Написала письмо маме в Ленинград, объяснила ситуацию и попросила помочь. Мама охотно согласилась взять Юлечку на время моей стажировки.

Осенью в ноябре 1970 года, всего через месяц после защиты кандидатской диссертации, я оказалась в Москве - в лаборатории Н.П. Дубинина в Институте общей генетики АН СССР. Тогда эта лаборатория располагалась на улице Ленина. Людмила Немцова стала моим ментором в освоении новой методики. Мы провели вместе три недели, каждый день работая допоздна. Мне повезло, что гостиница Академии наук, где я поселилась, была расположена совсем недалеко от Института. На работу можно было ходить пешком. Но возвращаться в гостиницу нужно было до 11 часов вечера, иначе вахтер ложился спать, и разбудить его была проблемой. Людмила никогда не уходила раньше меня, такое у нее было обычное расписание. Мы сидели за микроскопами вдвоем до позднего вечера в почти пустом Институте. К концу второй недели я вполне овладела методикой и даже увлеклась, анализируя всевозможные перестройки хромосом у креписа. Легко различала хромосомные разрывы, появляющиеся до начала репликации, от перестроек хроматид, которые возникают во время клеточного цикла при репликации хромосом. Сделала много фотографий и фактически могла бы уехать, но Немцова считала, что еще не время. Людмила стала привлекать меня к изучению собственных препаратов, которые были сложнее для анализа. Они содержали результаты опытов с модификациями дозы и условий облучения. Немцова приглашала посмотреть в ее микроскоп и дать свое истолкование видимого. Для меня это было самое интересное. Я почувствовала себя на равных, и Людмила, весьма строгая в общении женщина, потеплела. Расстались мы довольные друг другом. Перед отъездом она дала мне много семян и список лучших дозировок для их облучения.

Приехав в Новосибирск, я быстро наладила эту методику, приготовила препараты, и мы любовались митотическими пластинками с перестройками хромосом у облученных корешков креписа. Вера Вениаминовна была счастлива, ее мечта осуществилась. Методика вошла в большой цитогенетический практикум. В течение трех лет В.В. просила меня проводить занятия по перестройкам хромосом у облученных семян креписа. Затем молодые кафедральные ассистенты, Надя Назарова и Людмила Высоцкая, недавно окончившие НГУ, приглашали меня на эти классы, хотя уже хорошо владели методикой. «Так нам спокойнее, мы себя увереннее чувствуем», - объясняли они. Я с радостью окуналась в студенческую атмосферу, когда была свободна. До 1986 года (моего последнего года в ИЦиГ) эту методику использовали в программе практикума.

\section{Просветитель}

Вера Вениаминовна любила пропагандировать и распространять на большой круг ученых все новое, полученное в собственных исследованиях или работах коллег. Она умела объединять вокруг себя авторов, предлагая написать коллективную монографию. Так появилась книга «Цитогенетика пшениц и ее гибридов» (1971), в которой были собраны современные на тот период сведения по геномному анализу мягкой пшеницы, ее отдаленных гибридов, а также рассмотрены перспективы использования отдаленной гибридизации для селекции. В 1975 году Вера Вениаминовна совместно с московским цитологом Ю.Ф. Богдановым (он впервые в России стал успешно исследовать синаптонемальный комплекс, необходимый для синапсиса гомологичных хромосом, их рекомбинации и правильного расхождения) подготовили и выпустили монографию «Цитология и генетика мейоза» (1975). В этих двух трудах сотрудники лаборатории B.В. были соавторами. Подготовка статей и обзоров для данных монографий позволяла учиться кратко и ясно выражать свои мысли. Стараться излагать так, чтобы было понятно не 
только специалистам этой области. Основной список монографий и книг, написанных в соавторстве или под редакцией Веры Вениаминовны, приведен в публикациях о ней (100-летие..., 2003; Шумный и др., 2010, 2012) (краткий список представлен в Приложении).

Эти монографии-сводки читались специалистами. На одной из конференций по генетике и селекции растений ко мне подошли коллеги из Свердловска, Саратова, Одессы и задали разные вопросы о моем обзоре, представленном в «Цитогенетике пшениц и ее гибридов», который был посвящен использованию методов хромосомной инженерии в генетике и селекции. Те, кто читал обзор, нередко восклицали: «Мы думали вы намного старше, так все обстоятельно и такой обширный список литературы процитирован». Я отвечала, что в этом заслуга В.В. Хвостовой как научного редактора, поскольку она следила, чтобы мы не пропустили ни одной интересной современной работы. «Вам повезло», отвечали мне. И это чистая правда.

\section{Последние годы}

Авторитет и популярность Веры Вениаминовны в Институте цитологии и генетики были огромны. Многим хотелось знать ее мнение о написанной статье или диссертации, готовящейся к защите, или просто обсудить полученные данные. В.В., не жалея сил и не умея никому отказать в помощи, фактически стала консультантом и референтом работ сотрудников растениеводческих лабораторий всего Института. Она нам в шутку говорила, что в последнее время в основном читает неопубликованные статьи и незащищенные диссертации. Однако желание помочь молодому научному поколению превышали и усталость, и ограниченность времени.

В конце 1960-х, период политического потепления, свободнее стали контакты с зарубежными коллегами. Знание Верой Вениаминовной трех основных европейских языков помогало при визитах в Институт иностранных коллег-растениеводов. Без ее помощи не проходила ни одна встреча с научными гостями из Германии, Великобритании и США. Даже здоровый человек с трудом сдюжил бы такую каждодневную нагрузку. А Вера Вениаминовна страдала повышенным давлением, постоянно находилась под наблюдением врачей. В 1970-х годах она каждую осень уезжала в п. Узкое, ее любимое место Подмосковья, на курс санаторного лечения. Однако в последнее время санаторий уже мало помогал. Лечащие врачи Академгородка стали периодически помещать Веру Вениаминовну на обследование в клинику, не обращая внимания на ее яростное сопротивление этому. И так поддерживали ее здоровье последние годы.

И все же болезнь взяла свое. В начале осени 1976 года В.В. попала в больницу с тяжелым гипертоническим кризом. Лучшие врачи академического медицинского центра боролись за ее жизнь. Через недели три В.В. уже могла вставать. Нам троим - Фатиме Шкутиной, Екатерине Будашкиной и мне - по просьбе В.В. было разрешено навещать ее. Мы ежедневно посещали ее в отдельной палате столько, сколько разрешали лечащие врачи, помогали как могли. Вера Вениаминовна и в больнице интересовалась в основном событиями Института, преподаванием студентам ее любимой кафедры. Когда врачи разрешили в начале зимы короткие прогулки на улице, мы усаживали нашу В.В., укутанную в теплое одеяло, на финские санки с полозьями и возили по лесным утоптанным тропинкам городка. Все были счастливы, когда Веру Вениаминовну выписали домой - за пару недель до Нового года.

Наступил роковой 1977-й. Год начался с эпидемии гриппа, которая захватила и Академгородок. 30-го января Институт понес тяжелую утрату: не стало Юрия Яковлевича Керкиса, заведующего лабораторией общей и радиационной генетики, всеми уважаемого и любимого профессора. Вера Вениаминовна приняла эту потерю близко к сердцу. Они были соратниками и друзьями еще со времен их молодости в Москве в 1930-х годах. Оба были опальными генетиками. Пронесли уважение друг к другу сквозь годы насильственного отлучения от любимой работы. Вера Вениаминовна не могла смириться с этой утратой: «Он же моложе меня, такой жизнелюб; как такое могло случиться, какой-то грипп отнял его у нас», - сокрушалась она.

В начале марта В.В. поместили в клинику на ежегодное обследование. Однако на этот раз ее не выписали после 3-4 недель. Определили какие-то нарушения в функции сердца, давление не понижалось. Улучшения не наблюдалось, настроение Веры Вениаминовны было плохим, она теряла веру в выздоровление. Мы пытались вселять в нее оптимизм, и вдруг каким-то чудом ситуация изменилась. В.В. стало получше, ее выписали домой. Стоял апрель. Вера Вениаминовна была очень оживлена, рассказывала, что купила билеты в Москву, соскучилась по дочери Наташе и любимым внукам Володе и Алене и хочет свой день рождения, 29 апреля, отпраздновать в кругу семьи.

И.И. Кикнадзе и мы втроем из лаборатории по-прежнему опекали Веру Вениаминовну. Заботились, чтобы она больше отдыхала и набиралась сил на поездку. Только мы начали немного успокаиваться, и вдруг в один из дней на работу звонит Ия Ивановна и просит срочно быть у В.В., состояние которой ухудшилось. Мы прибежали домой к Вере Вениаминовне и увидели безотрадную картину - так она изменилась за одну ночь. Минут через пятнадцать приехала скорая помощь. Когда санитары с носилками появились в квартире, В.В. поняла, что ее забирают в госпиталь. Она пыталась что-то нам поведать и, показывая рукой куда-то в сторону, хотела что-то объяснить. Речь уже заплеталась, была нечленораздельной, несвязной. Однако я отчетливо разобрала: «Хочууу... Москва». И так она повторяла весь скорбный путь из квартиры на третьем этаже до машины скорой помощи. Это был последний раз, когда мы видели Веру Вениаминовну. Врачи были бессильны ее спасти. 22 апреля 1977 года Веры Вениаминовны не стало. Мы осиротели.

\section{Заключение}

Дело, которое началось с благословления Веры Вениаминовны Хвостовой, продолжает успешно развиваться. Прогресс в изучении мейоза, включая проблему генетического контроля, отражен в недавней книге «Консерватизм, изменчивость и эволюция мейоза» (Богданов, Гришаева, 2020) и статье С.А. Симановского и Ю.Ф. Богданова (2018). В этих двух источниках представлены и клонированные мейоти- 
ческие гены разных организмов, в том числе кукурузы. Показана функция основных белков специфичных для мейоза, принимающих участие в осуществлении инициации мейоза, конъюгации гомологичных хромосом, их рекомбинации и сегрегации. Цитируют и наши современные статьи о мейотических мутациях генов кукурузы. Думаю, что созданная коллекция мей-мутантов кукурузы сослужит благородную службу ученым. В 2010 году коллекция бережно подготовлена и передана мною в Фонд генетических коллекций в Иллинойсе (США) и каталог мировой коллекции ВИР (СанктПетербург, Россия).

\section{Список литературы / References}

100-летие со дня рождения профессора Веры Вениаминовны Хвостовой. Информачионный вестник ВОГИС. 2003;(24-25):24-34.

[The 100 years birth anniversary of Professor Vera Veniaminovna Khvostova. Informatsionnyy Vestnik VOGiS = The Herald of Vavilov Society for Geneticists and Breeding Scientists. 2003;(24-25):24-34. (in Russian)]

Богданов Ю.Ф., Гришаева Т.М. Консерватизм, изменчивость и эволюция мейоза. М.: Товарищество научных изданий КМК, 2020;342. [Bogdanov Yu.F., Grishaeva T.M. Conservatizm, variation and evolution of meiosis. Moscow: KMK Scientific Press, 2020;342. (in Russian)]

Голубовская И.Н. Цитогенетика отдаленнных гибридов и перспективы и использование в селекции. В: Цитогенетика пшениц и ее гибридов. Под ред. П.М. Жуковского, В.В. Хвостовой. М.: Наука, 1971;243-286.

[Golubovskaya I.N. Cytogenetics of distant hybrids and perspective their using in breeding. In: Zhukovsky P.M., Khvostova V.V. (Eds.). Cytogenetics wheat and hybrids. Moscow: Nauka Publ., 1971;243286. (in Russian)]

Голубовская И.Н., Машненков А.С. Мейотическая мутация у кукурузы afd1. Генетика. 1975;11:11-17.

[Golubovskaya I.N., Mashnenkov A.S. Meiotic mutant of maize afd1. Genetika. 1975;11:11-17.]

Захаров И.К., Колчанов Н.А., Шумный В.К. Профессор Ия Ивановна Кикнадзе. К 80-летию со дня рождения и к 55-летию научно-педагогической деятельности. Вавиловский журнал генетики и селекции. 2010;14(1):11-21.

[Zakharov I.K., Kolchanov N.A., Schumny V.K. Professor lya Ivanovna Riknadze. The 80 years birth anniversary and 55 years of the scientific educational activity. Vavilovskii Zhurnal Genetiki i Selektsii = Vavilov Journal of Genetics and Breeding. 2010;14(1):11-21. (in Russian)]

Захаров-Гезехус И.А. Выдвиженец по курсу общей генетики. Василий Сергеевич Федоров и его школа. М., 2018.

[Zakharov-Gezekhus I.A. Promoted person in course of General Genetics. Vasily Sergeevich Fedorov and his school. Moscow, 2018. (in Russian)]

Инге-Вечтомов С.Г., Тихомирова М.М., Кайданов Л.З. Михаил Ефимович Лобашев (к 90-летию со дня рождения). Генетика. 1997;33(10):1450-1454.

[Inge-Vechtomov S.G., Tikhomirova M.M., Kaidanov L.Z. Mikhail Efimovich Lobashov (The 80 years birth anniversary). Genetika. 1997;33(10):1450-1454. (in Russian)]

Лапченко Г.Д. Применение метода отдаленной гибридизации в селекции озимой пшеницы. Селекция и семеноводство. 1967;(2): 33-38.

[Lapchenko G.D. Application of the method of remote hybridization in the selection of winter wheat. Selectiya $i$ semenovodstvo. 1967;(2):33-38. (in Russian)]

Симановский С.А., Богданов Ю.А. Генетический контроль мейоза у растений. Генетика. 2018;54(4):397-411. DOI 10.7868/ S0016675818040021.

[Simanovsky S.A., Bogdanov Yu.A. Genetics control of meiosis in plants. Russ. J. Genet. 2018;54(4):389-402. DOI 10.1134/ S1022795418030122.]
Цитогенетика пшеницы и ее гибридов. Под ред. П.М. Жуковского, В.В. Хвостовой. М.: Наука, 1971;287.

[Cytogenetics wheat and hybrids. Zhukovsky P.M., Khvostova V.V. Moscow (Eds.). Moscow: Nauka Publ., 1971;287. (in Russian)]

Цитология и генетика мейоза. Под ред. В.В. Хвостовой, Ю.Ф. Богданова. М.: Наука, 1975;432.

[Cytology and genetics of meiosis. Khvostova V.V., Bogdanov Yu.F. (Eds.). Moscow: Nauka Publ., 1975;432. (in Russian)]

Шумный В.К., Будашкина Е.Б., Кикнадзе И.И., Захаров И.К. Вера Вениаминовна Хвостова, Учитель и Друг. Новосибирск: Наука, 2010;217.

[Schumny V.K., Budashkina E.B., Kiknadze I.I., Zakharov I.K. Vera Veniaminovna Khvostova. Teacher and Friend. Novosibirsk: Nauka Publ., 2010;217. (in Russian)]

Шумный В.К., Захаров И.К., Кикнадзе И.И., Иванова Л.Н., Попова Н.К., Дымшиц Г.М. Генетика прирастает Сибирью. Новосибирск: Изд-во СО РАН, 2012;352.

[Schumny V.K., Zakharov I.K., Kiknadze I.I., Ivanova L.N., Popova N.K., Dimshits G.M. Genetics increases with Siberia. Novosibirsk: SO RAN Publ., 2012;352. (in Russian)]

All-Kaff N., Knight E., Berlin I., Foote T., Hart N., Griffiths S., Moore G. Detailed dissection of the chromosomal region containing the Ph1 locus in wheat Triticum aestivum with deletion mutants and expression profiling. Ann. Bot. 2008;101(6):863-872. DOI 10.1093/aob/mcm 252.

Feldman M. The effect of chromosomes 5B, 5D, and 5A on chromosomal pairing in Triticum aestivum. Proc. Natl. Acad. Sci. USA. 1968;55(6):1447-1453. DOI 10.1073/pnas.55.6.1447.

Greer E., Vartin A.C., Pendle A., Colas I., Jones A., Moore G., Shaw P. The Ph1 locus suppresses CDK2-type activity during premeiosis and meiosis in wheat. Plant Cell. 2012;24(1):152-162. DOI 10.1105/ tpc.111.094771.

Griffiths S., Sharp R., Foote T., Bertin I., Wanous M., Reader S., Colas I., Moore G. Molecular characterization of $\mathrm{Ph} 1$ as a major chromosome pairing locus in polyploid wheat. Nature. 2006;439(7077):749-752. DOI 10.1038/nature04434.

Golubovskaya I.N., Hamant O., Timofejeva L., Wang C.-J.R., Braun D., Meeley R., Cande W.Z. Alleles of afd 1 dissect REC8 functions during meiotic prophase I. J. Cell Sci. 2006;119(Pt 16):3306-15. DOI 10.1242/ jcs.03054.

Golubovskaya I.N., Wang R., Timofejeva L., Cande W.Z. Maize meiotic mutants with improper or nonhomologous synapsis due to problems in pairing or synaptonemal complex formation. J. Exp. Bot. 2011;62(5):1533-44. DOI 10.1093/jxb/erq292.

Kitajima T.C., Miyazaki Y., Yamamoto M., Watanabe Y. Rec8 cleavage by separaseis required for meiotic nuclear division in fission yeast. EMBO J. 2003;22(20):5643-53. DOI 10.1093/emboj/cdg527.

Riley R. Cytogenetics of chromosome pairing in wheat. Genetics. 1974;78(1):193-203.

Riley R., Chapman V. Genetic control of cytologically diploid behavior of hexaploid wheat. Nature. 1958;182:713-715.

Salina E.A., Nesterov M., Frenkel Z., Kiseleva A.A., Timonova E.M., Magni F., Vrana J., Safat J., Simkova H., Dolezel J., Korol A., Sergeeva E.M. Features of the organization of bread wheat chromosome on 5BS based on physical mapping. BMC Genome. 2018;19(Suppl. 3):80.

Sears E. An induced mutant with homoeologous pairing in common wheat. Can. J. Genet. Cytol. 1977;19:585-593.

Sears E.R. The aneuploids of common wheat. Research Bulletin. University of Missouri, Agricultural Experimental Station, 1954;572:1-58.

Sears E.R., Okamoto M. Intergenomic relationships in hexaploid wheat. Proc. X Intern. Congr. Genet. 1958;2:258-259.

Sergeeva E.M., Afonnikov D.A., Koltunova M.K., Gusev V.D., Miroshnichenko L.A., Vrana J., Kubalakova M., Poncet C., Sourdille P., Feuillet C., Dolezel J., Salina E.A. Common wheat chromosome 5B composition analysis using low-coverale 454 sequencing. Plant Genome. 2014;7(2):1-16.

Wall A.M., Riley R., Chapman V. Wheat mutants permitting homoeologous meiotic chromosome pairing. Genet. Res. 1971;18(3):311-328. 


\section{Приложение}

Избранные публикации В.В. Хвостовой по цитогенетике пшениц и отдаленных гибридов (1961-1977)

Хвостова В.В., Ячевская Г.Л. Изучение мейоза у константных 56-хромосомных промежуточных форм пшенично-пырейных гибридов. Докл. АН СССР. 1961;138(1):215-218.

Хвостова В.В., Ячевская Г.Л., Лункина А.И. Мейоз у неполных пшенично-пырейных амфидиплоидов. В: Полиплоидия и селекция. М.-Л.: Наука, 1965;123-128.

Хвостова В.В. Индуцированные мутации и их практическое использование. Генетика. 1966;2(10):183-188.

Шкутина Ф.М. Хвостова В.В. Цитологический анализ пшенично ржаных амфидиплоидов. В: Экспериментальная полиплоидия и селекция растений. Под ред. В.Б. Енкена, А.Н. Луткова, О.И. Майстренко, Г.Ф. Привалова, П.К. Шкварникова. Новосибирск: Наука, $1966 ; 261-266$.

Голубовская И.Н., Никоро 3.С., Хвостова В.В. Анализ возможности отбора на повышение плодовитости у константных 56-хромосомных пшенично-пырейных гибридов. Генетика. 1966;(4):86-96.

Хвостова В.В. Механизмы действия разных видов ионизирующих излучений на семена растений и проблема радиоустойчивости. Изв. СО АН СССР. Сер. биол. нук. 1967;5(1):118-122.

Голубовская И.Н., Шкутина Ф.М., Хвостова В.В. Нестабильность числа хромосом, обнаруженная в мейозе у пшенично-ржаных и неполных пшенично-пырейных амфидиплоидов. Генетика. 1967;3(1):25-31

Шкутина Ф.М., Голубовская И.Н., Хвостова В.В. Анеуплоидия пшенично-ржаных $(2 n=56)$ и неполных пшенично-пырейных $(2 n=56)$ амфидиплоидов. Генетика. 1967;3(12):20-30.

Хвостова В.В. Цитогенетический анализ пшенично-ржаных амфидиплоидов и пшенично-пырейных гибридов в связи с проблемой их плодовитости. В: Отдаленная гибридизация растений. Зерновые и зернобобовые культуры. М.: Колос, 1970;274-280.

Голубовская И.Н., Никоро 3.С., Хвостова В.В. Анализ возможности отбора на повышение плодовитости у константных 56-хромосомных пшенично-пырейных неполных амфидиплоидов. Сообщение 2. Генетика. 1970;2:5-13.

Будашкина Е.Б., Коробейникова М.Х., Хвостова В.В. Цитогенетическое изучение межвидовых гибридов пшениц Triticum aestivum $\times$ Triticum dicoccum. Сообщение 1. Генетика. 1971;7(9):5-12.

Khvostova V.V., Shkutina F.M. Cytological investigation of Triticale. Theor Appl. Genet. 1971;41(3):109-119.
Хвостова В.В., Голубовская И.Н., Шкутина Ф.М. Цитогенетика аллополиплоидов подтрибы Triticinae на примере Triticale и 56-хромосомных ППГ (неполных амфидиплоидов). В: Полиплоидия и селекция. Минск: Наука и техника, 1972;95-105.

Хвостова В.В., Будашкина Е.Б. Экспериментальный мутагенез в селекции растений на устойчивость к болезням. Сиб. вестн. с.-х. науки. 1972;3(9):36-40.

Хвостова В.В., Будашкина Е.Б. Экспериментальный мутагенез в селекции растений на устойчивость к болезням. В: Генетические основы селекции растений на иммунитет. М.: Наука, 1973;204231.

Голубовская И.Н., Хвостова В.В., Шкутина Ф.М. Десинапсис - основная причина нарушения мейоза амфидиплоидов. В: Половой процесс в эмбриогенезе растений. Материалы всесоюзного симпозиума, посвященного 75-летию открытия академиком С.Г. Навашиным двойного оплодотворения у покрытосеменных растений. М., 1973;53-54.

Хвостова В.В., Щапова А.И. Дифференциальная окраска хромосом ржи и ее значение в цитогенетике Тритикале. Изв. СО АН СССР. Сер. биол. наук. 1974;15(3):70-74.

Хвостова В.В. Методика исследования мейоза. В: Генетические методы селекции растений. Под ред. Н.В. Турбина. М.: Колос, 1974;192-195.

Козловская В.Ф., Хвостова В.В. Цитогенетический анализ мутантов 56-хромосомных Тритикале. Сообщение 2. Генетика. 1976;12(6):5-13.

Козловская В.Ф., Хвостова В.В. Цитогенетический анализ мутантов 56-хромосомных Тритикале. Сообщение 3. Генетика. 1976;12(7):8-15.

Першина А.А., Хвостова В.В. Феногенетика мутантов гороха с изменчивой структурой стебля. В: Цитогенетика гибридов, мутации и эволюция кариотипов. Новосибирск: Наука, 1977; 167-181.

Хвостова В.В., Будашкина Е.Б., Голубовская И.Н., Шкутина Ф.М., Щапова А.И., Усова Т.К. Цитогенетика отдаленных гибридов пшеницы. В: Фундаментальные исследования. Биологические науки. Под ред. В.Ф. Альтергота, И.И. Гительзона, А.Б. Жукова, И.А. Клеванской, Р.В. Ковалева, Л.И. Корочкина, Л.И. Малышева, В.В. Хвостовой, Б.С. Юдина. Новосибирск: Наука, 1977;142-145.

Конфликт интересов. Автор заявляет об отсутствии конфликта интересов.

Поступила в редакцию 12.05.2021. После доработки 19.05.2021. Принята к публикации 21.05.2021. 